\title{
Okavango Basin - Hydrology
}

Table 1: General information and key figures.

\begin{tabular}{|c|c|c|}
\hline Other names & Countries & Region \\
\hline Kawango & Angola, Namibia, Botswana & Southern Africa \\
\hline Tributaries west (Cubango Catchment) & Tributaries east (Cuito Catchment) & Cities \\
\hline $\begin{array}{l}\text { Cubango, Cutato, Chuchi, Cacuchi, } \\
\text { Celei, Cuebe, Cueio, Cuatir }\end{array}$ & $\begin{array}{l}\text { Cuito, Cuanavale, } \\
\text { Lussinga, Longa, Cuiriri }\end{array}$ & $\begin{array}{l}\text { Menongue (Angola), } \\
\text { Rundu (Namibia), Maun (Botswana) }\end{array}$ \\
\hline Source & Source location & Source elevation \\
\hline $\begin{array}{l}\text { Bié Plateau } \\
\text { (Central Plateau of Angola) }\end{array}$ & $\begin{array}{l}\text { Close to Tchicala Tcholohanga } \\
\text { (other names: Vila Nova, Chicala } \\
\text { Choloanga) near the } \\
\text { village/settlement of Lumbula }\end{array}$ & $1,850 \mathrm{~m}$ approx. \\
\hline Source coordinates & Mouth & Mouth elevation \\
\hline $\begin{array}{l}12^{\circ} 42^{\prime} 40.76^{\prime \prime} \mathrm{S} \\
16^{\circ} 03^{\prime} 50.48^{\prime \prime} \mathrm{E}\end{array}$ & $\begin{array}{l}\text { Between Seronga (east) and } \\
\text { Ikoga (west) into the Okavango } \\
\text { Delta (Botswana) }\end{array}$ & $\begin{array}{l}\text { Outlet of the Panhandle between } \\
\text { Seronga and lkoga: } 980 \text { m; Maun: } \\
940 \text { m (Delta outlet) }\end{array}$ \\
\hline Mouth coordinates & Length & Basin \\
\hline $\begin{array}{l}18^{\circ} 50^{\prime} 40.76^{\prime \prime} \mathrm{S} \\
16^{\circ} 03^{\prime} 50.48^{\prime \prime} \mathrm{E}\end{array}$ & $\begin{array}{l}\text { Cubango: } 1,260 \mathrm{~km} \text { approx., } \\
\text { Cuito: } 920 \mathrm{~km} \text { approx., } \\
\text { Okavango (including the Delta } \\
\text { until Maun): } 1,860 \mathrm{~km} \text { approx. }\end{array}$ & $\begin{array}{l}165,000 \mathrm{~km}^{2} \text { approx. (until the } \\
\text { entrance into the Panhandle at } \\
\text { Mohembo) }\end{array}$ \\
\hline \multicolumn{3}{|l|}{ Discharge average } \\
\hline \multicolumn{3}{|c|}{$304 \mathrm{~m}^{3} \mathrm{~s}^{-1}$ approx (Station Mukwe, 10/1949 - 09/1998)* } \\
\hline
\end{tabular}

* for flow characteristics, see Figure 3

The Okavango River has its origin in the semi-humid highlands of Angola and drains the endorheic Okavango River basin through the arid and semi-arid eastern parts of Namibia into Botswana where it drains into a wetland, also known as the Okavango Delta (Fig. 1). The Okavango River basin upstream of the Delta covers an area of about $171,000 \mathrm{~km}^{2}$ (Mohembo). About 95\% of the streamflow entering the Delta is generated by two main tributaries, namely the Cubango River $\left(108,000 \mathrm{~km}^{2}\right)$ and the Cuito River $\left(57,470 \mathrm{~km}^{2}\right)$, both located in Angola. The ephemeral Omatako River originates in Namibia and joins the Cubango River near Rundu, but has not contributed to runoff from the Okavango for over 50 years.

The Cubango River (flow length of $1,260 \mathrm{~km}$ ) has its source in the eastern part of Huambo Province close to the village of Tchicala Tcholohanga (1,850 $\mathrm{m}$ above sea level (a.s.1.), whereas the Cuito River (flow length of $920 \mathrm{~km}$ ) rises between Cangoa and Sachiambe (1,430 m a.s.1.) in the western part of Moxico Province (Fig. 2). After the confluence of both rivers south of Dirico the river becomes the

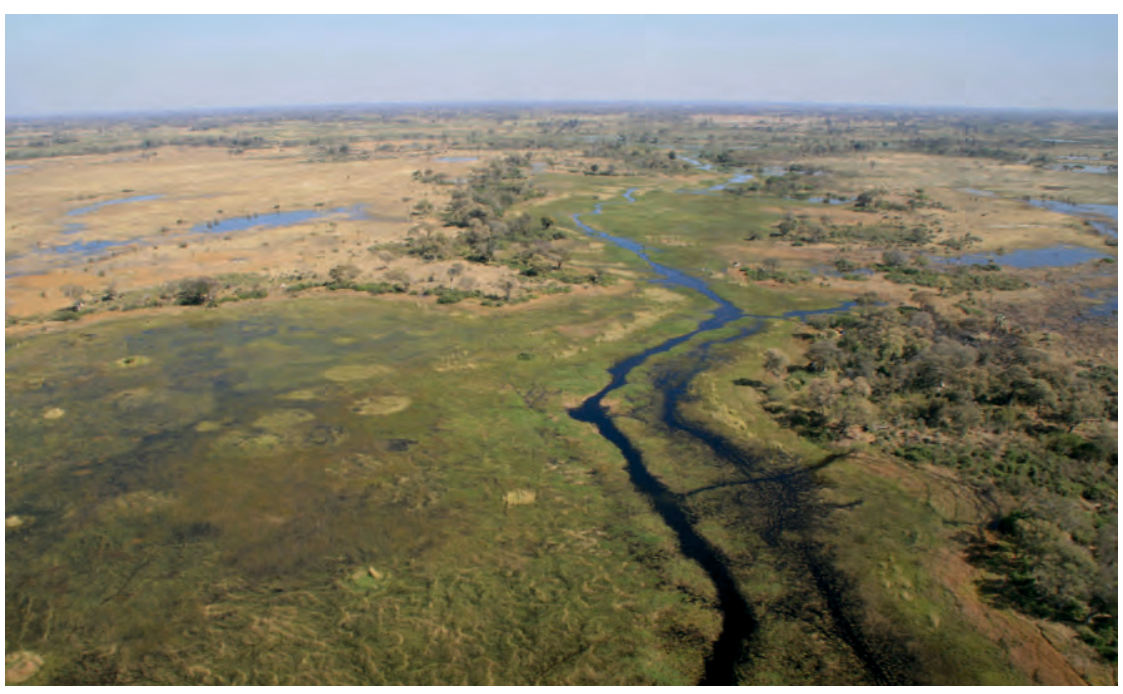

Fig. 1: The Okavango Delta in August 2009 (photo: J. Helmschrot).

"Okavango River" (Cubango River in Angola and Kavango River in Namibia). Flowing in a southeasterly direction, the Okavango River passes the gauging stations Mukwe and Mohembo where historic annual discharge of about $10 \mathrm{~km}^{3}$ finally spills through the Panhandle and subsequently into the Okavango Delta at an elevation of $980 \mathrm{~m}$ a.s.l. The different flow regimes and associated main runoff generation mechanisms of both tributary basins (active drainage area) are strongly controlled by both climatic conditions and landscape characteristics, including geological and soil conditions as well as topography. According to the strong precipitation gradient in the basin, where the highest annual precipitation is in the 


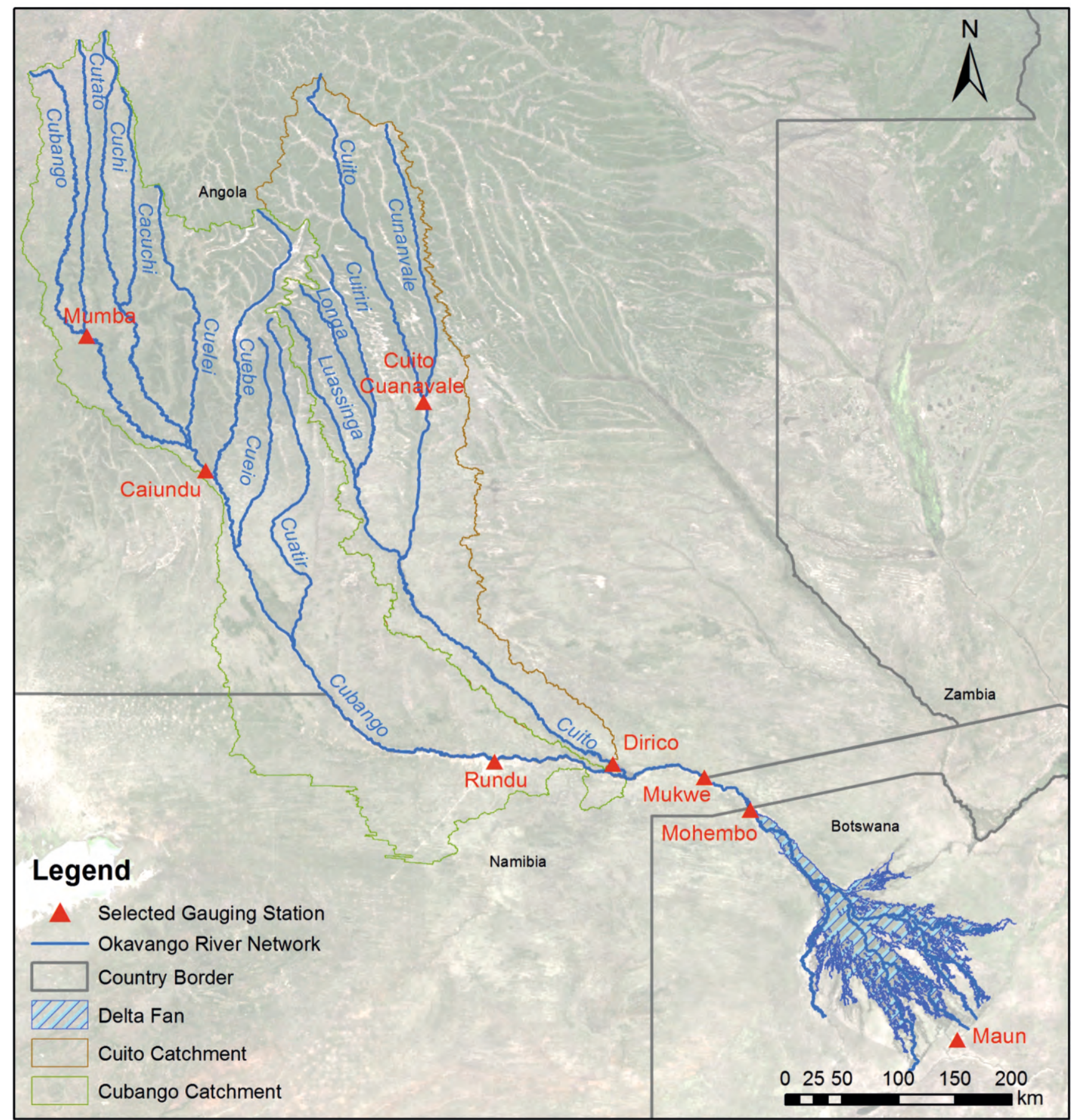

Fig. 2: Okavango River Basin including all main tributaries and the Okavango Delta with its entrance at Mohembo gauging station and outlet at Maun (data source: NIWR, ORI; background: MODIS 16-day BRDF-adjusted NBAR data (MCD43A4) courtesy of EOSDIS-NASA).

northeast (1,200-1,300 mm, Huambo) and the lowest annual precipitation is in the southwest $(<500 \mathrm{~mm}$, Rundu and Maun) (FAO 2001), almost all discharge is generated in the headwaters during the rainfall season between October and March. The hilly landscape of the Cubango and parts of the Cuito headwaters are dominated by igneous and metamorphic rocks forming granitic, sometimes shallow soils, supporting surface runoff and rapid subsurface flows rather than baseflow generation. In contrast, most of the flat north-eastern and southern parts of the Cubango basin as well as wider parts of the Cuito basin are covered with thick-layered sedimentary formations from the Kalahari group. These areas affected by sandy deposits show a moderate topography allowing for high percolation rates and groundwater recharge. The river morphology also notably controls the discharge of both basins (Fig. 3, Fig 4.). Abrupt incised valleys also promote rapid runoff generation in the upper Cubango and explain the sharp increase of the hydrograph with the beginning of the rainy season. The wider valleys of the Cuito basin with their densely vegetated swampy bottoms, floodplains and meanders decelerate the runoff and provide moderate hydrographs with significantly higher baseflow contributions than observed in the Cubango system.

The different flow regimes are also reflected in observed runoff volumes. As shown by daily data for the period between 1945 and 2000, the mean annual runoff of the Cubango at Rundu is $165 \mathrm{~m}^{3} \mathrm{~s}^{-1}$ with the highest runoff in April $\left(393 \mathrm{~m}^{3} \mathrm{~s}^{-1}\right)$ and the lowest runoff in October $\left(38.9 \mathrm{~m}^{3} \mathrm{~s}^{-1}\right)$. 


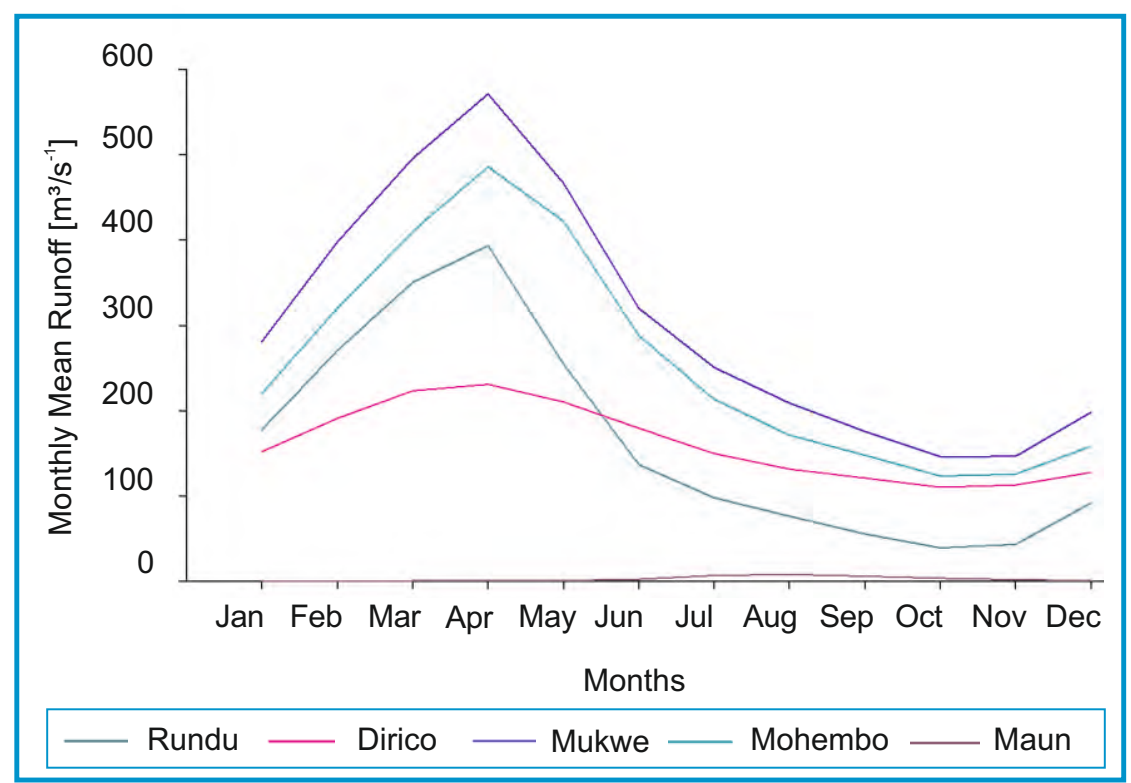

Fig. 3: Monthly mean discharge values describing the inner-annual flow characteristics and flood pulse pattern at representative gauging stations (Mukwe: 1949-1998, Rundu: 1945-2000, Dirico: 1962-1975, Mohembo: 1974-2002, Maun: 19802000) along the Okavango River (data source: NIWR, GRDC, ORI).
Similar timing can be observed for the Cuito at Dirico. However, the moderate runoff peak in April $\left(230.7 \mathrm{~m}^{3} \mathrm{~s}^{-1}\right)$ and a significantly higher runoff during low flow conditions in October $\left(110.2 \mathrm{~m}^{3} \mathrm{~s}^{-1}\right)$ are a result of the retention functions and sustained water release from the wetlands and floodplains. The analysis of upstreamdownstream effects showing varying water travel times in both tributaries underpin differences in the runoff generation mechanisms. Analysis of runoff events observed at the gauging stations at Mumba (upstream of Cubango) and Rundu (Fig. 5; $500 \mathrm{~km}$ downstream) shows that the travel time of an individual peak is up to 10 days in the Cubango River. In contrast, the travel time of the flood peak between Cuito Cuanavale (upstream of Cuito) and Dirico (270 km) is four times longer. However, the relatively low travel times and high wetland storage functions favour the retention of sediments and

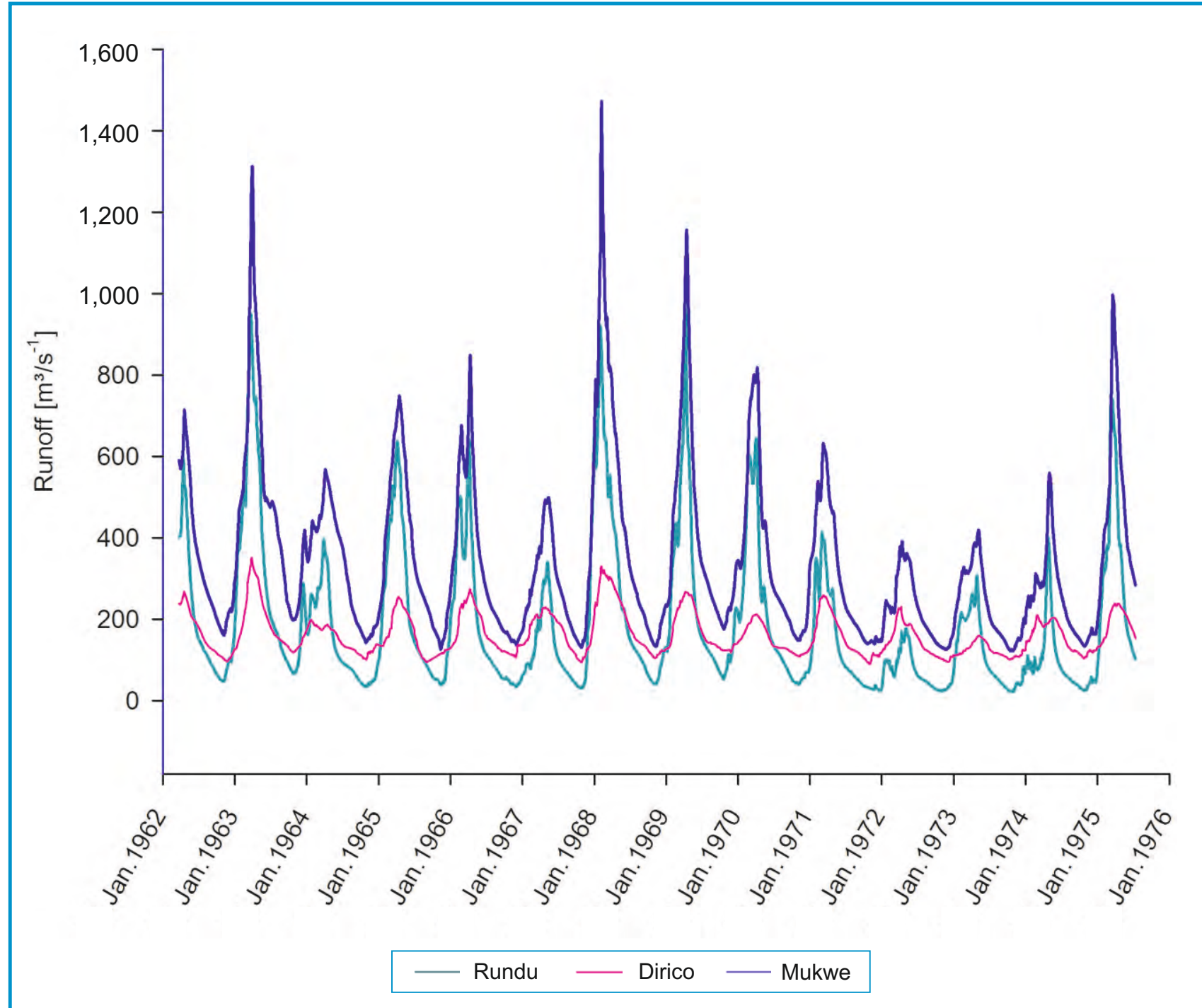

Fig. 4: Daily runoff at Rundu (Cubango), Dirico (Cuito), and Mukwe (Okavango) stations between 1962 and 1975 (data source: NIWR, GRDC). 
nutrients from leached sandy soils and, thus, cause clear, nutrient poor river water.

At the Mukwe gauging station, which is close to the confluence of both tributaries, the mean annual runoff increases up to $304.7 \mathrm{~m}^{3} \mathrm{~s}^{-1}$. The discharge reaches its maximum of $571.3 \mathrm{~m}^{3} \mathrm{~s}^{-1}$ in April and drops to $145.2 \mathrm{~m}^{3} \mathrm{~s}^{-1}$ during low flow conditions in October. The mean daily runoff volume at Mukwe is $26.3 * 10^{6} \mathrm{~m}^{3}(1949-1998)$ which equals $57 \mathrm{~mm}^{*} \mathrm{a}^{-1} * \mathrm{~m}^{-2}$ of the catchment. Before entering the Delta, the Okavango also loses water between Mukwe and Mohembo through evaporation, groundwater losses, and water extraction. The mean daily runoff entering the Okavango Delta at Mohembo is $6 \%$ less than the runoff at the gauging station at Mukwe. Consequently, the mean annual daily runoff at Mohembo (1974$1998)$ is $263 \mathrm{~m}^{3} \mathrm{~s}^{-1}$. The highest difference in monthly streamflow occurs in January and is $21 \%$ lower compared to the runoff in Mukwe $\left(281 \mathrm{~m}^{3} \mathrm{~s}^{-1}\right)$.

The Okavango Delta is situated in two sets of parallel faults, oriented perpendicular to each other, underlain by deep Kalahari sands. With mean annual precipitation and potential evapotranspiration of $450 \mathrm{~mm}$ and $2,000 \mathrm{~mm}$ respectively, it receives almost all of its water as a flood pulse from its headwaters in the Angolan highlands. The flood pulse peaks in Mohembo around April/ May. Due to the nearly flat topography (slope ratio in metres of 1 in 3,500), the flood takes about three to four months to traverse the Delta, a distance of about $250 \mathrm{~km}$, reaching the seasonal Thamalakane River, the main outlet from the Delta, in July/ August. This only happens when sufficient water flows into the Delta in Mohembo, coupled with local precipitation and antecedent soil moisture in the Delta. Almost $95 \%$ of the inflow is lost to evapotranspiration in the Delta. The total flooded area of the Delta varies annually, depending on the total inflow volume at Mohembo and the previous year inflow. It ranges between approximately $6,000 \mathrm{~km}^{2}$ of permanent swamps, and $12,000 \mathrm{~km}^{2}$ due to the flooding of seasonal and occasional floodplains.

Mainly because of civil war in Angola, which ended in the early 2000s, and the high prevalence of insect-borne diseases

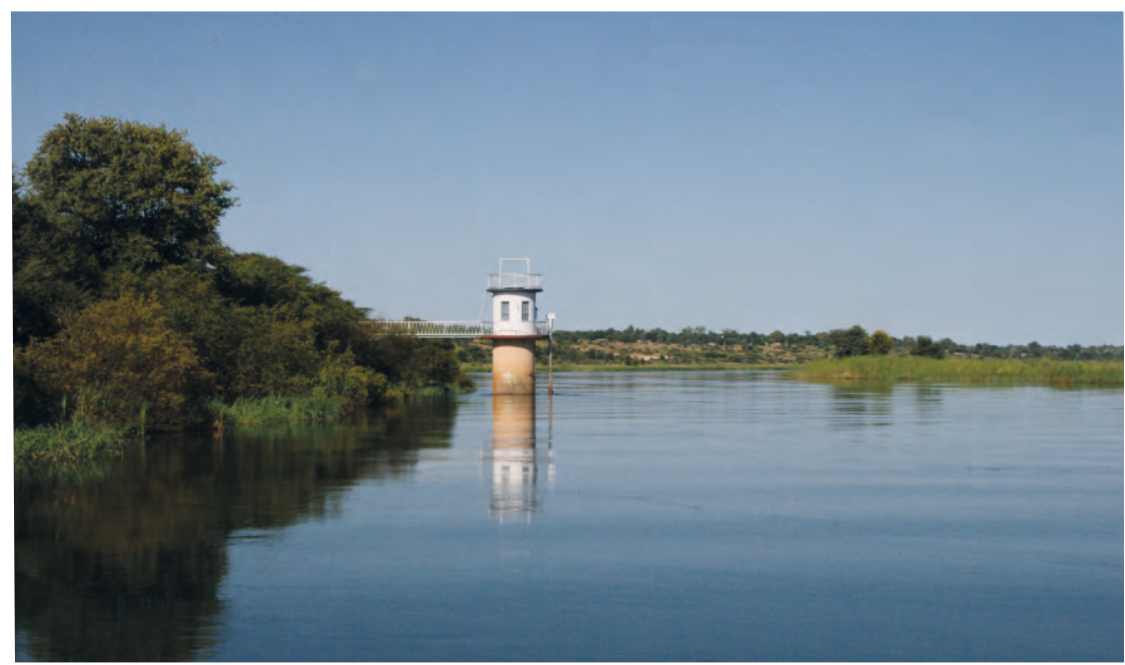

Fig. 5: Gauging station at Rundu (photo: H. Göhmann).

in the Delta, the river basin, together with the Delta, has been minimally impacted by anthropogenic activities. However, with the end of the war in Angola and the eradication of the insect-borne diseases in the Delta, the basin is facing increasing pressure due to land use/land cover changes, water abstractions, and pollution. These all have the potential to negatively impact the flow distribution of the basin. Their impact will be exacerbated by the impacts of climate change.

\section{Acknowledgements}

This study was funded by the BMBF (The Future Okavango project). For details see authors' general acknowledgements in this volume.

\section{Reference}

FAO (Food and Agricultural Organization of the United Nations) (2001): FAOCLIM 2.0 A World-Wide Agroclimatic Database. - Food and Agriculture Organization of the United Nations: Rome, Italy.

Responsible authors: T. Steudel, H. Göhmann, E. Mosimanyana, M. Quintino, W.-A. Flügel, J. Helmschrot 